Revue bibliographique pour le domaine irano-aryen

\title{
Abolala Soudavar. Reassessing Early Safavid Art and History. Thirty-Five Years after Dickson \& Welch 1981
}

\section{Iván Szántó}

\section{(2) OpenEdition Journals}

Electronic version

URL: http://journals.openedition.org/abstractairanica/42748

DOI: $10.4000 /$ abstractairanica. 42748

ISBN: 1961-960X

ISSN: 1961-960X

Publisher:

CNRS (UMR 7528 Mondes iraniens et indiens), Éditions de l'IFRI

\section{Electronic reference}

Iván Szántó, «Abolala Soudavar. Reassessing Early Safavid Art and History. Thirty-Five Years after Dickson \& Welch $1981 »$, Abstracta Iranica [Online], Volume 37-38-39 | 2018, document 17, Online since 10 March 2018, connection on 26 September 2020. URL : http://journals.openedition.org/ abstractairanica/42748 ; DOI : https://doi.org/10.4000/abstractairanica.42748

This text was automatically generated on 26 September 2020.

Tous droits réservés 


\title{
Abolala Soudavar. Reassessing Early Safavid Art and History. Thirty-Five Years after Dickson \& Welch 1981
}

\author{
Iván Szántó
}

\section{REFERENCES}

Abolala Soudavar. Reassessing Early Safavid Art and History. Thirty-Five Years after Dickson \& Welch 1981, Houston: Abolala Soudavar, 2016, 95 p. ISBN: 9781329976153

1 The volume consists of seven individual studies which are bound together by their strong reliance on The Houghton Shahnameh (Cambridge, Mass., 1981) by Martin Bernard Dickson and Stuart Cary Welch and the deference of the author to this two-volume work. While the author engages multiple problems in the respective chapters, his overarching concern is for "Dickson \& Welch 1981": a seminal volume which Soudavar believes to have been unjustly marginalised, ignored, and/or criticised by subsequent scholarship. To disprove sceptics, he seeks to defend the book against its critics and demonstrate the usefulness of its methodology by applying it to new material, even though Soudavar is ready to contradict any of Dickson's and Welch's attributions if he disagrees with it. Through this new book, the reader can recognise traces of Soudavar's indebtedness to the two authors in his earlier studies, most notably in The Saga of AbuSa'id Bahādor Khān: The Abu-Sa'idnāmé (in Oxford Studies In Islamic Art, XII, 1996) and Art of the Persian Courts (New York, 1992) where he already emulated the task-sharing of art historian Welch and historian Dickson in "reading" the pictorial semantics of epic illustrations as allusions to real-life events. The articles of this book treat their subject in a similar manner, their main tasks being, on the one hand, correctly attributing certain problematic paintings, and, on the other hand, finding their historiographic context. 
2 After the introductory remarks of chapter I, the case study in chapter II confirms Dickson's and Welch's attribution of two detached paintings (Harvard University Art Museum 1958.75 and 76) to Mīr Sayyed 'Alī, invalidating Oleg Grabar's and Mika Natif's rejection of this attribution (see Grabar, Oleg, and Natif, Mika, "Two Safavid Paintings: An Essay in Interpretation", in Muqarnas, 18, 173-202). He suggests that even if the two paintings do not display lines from any poem, they might have been originally intended for the royal Nezāāmi manuscript of Shah Ṭahmāsp I (London, British Library, OR. 2265) and their inclusion and eventual removal from the manuscript are explainable through the ever-changing political constellation during the shah's early rule. Chapters III and VI are similar in that both deal with a pair of signatures which are interpreted by certain critics of Dickson and Welch to hide one and the same person. In chapter III, Barbara Brend's intention to identify Mīrzā 'Alī with 'Abd al-Ṣamad is criticised (Brend, Barbara, "Another Career for Mīrzā 'Alī”, in: Newman, Andrew [ed.], Society and Culture in the Early Modern Middle East: Studies on Iran in the Safavid Period, Leiden - Boston: Brill, 2003, 213-235). In chapter VI the indefensibility of a similar suggestion by Ebadollah Bahari (Bahari, Ebadollah, Bihzād: Master of Persian Painting, London: I. B. Tauris, 1996), with respect to Šaykh-Zāda and Mahmūd-Modahheb, is argued for. The target of chapter IV is also Bahari and his dating of a Panj Ganj manuscript in his own collection which shows parallels with a dispersed royal Safavid Dìvān of Ḥăfez formerly known as the Cartier Hâfez. This chapter compares the later Safavid derivatives of early Safavid book production with the early- $20^{\text {th }}$ century forgeries of the same material. Chapter $\mathrm{V}$ continues to examine the Cartier Divān of H̦âfez, this time from a historical perspective, and goes on to identify some of the protagonists of the standoff between Shah Ṭahmāsp I and his brother Sām Mīrzā among the figures in the illustrations of this and other manuscripts of poetry. Finally, chapter VII returns to the question of early $20^{\text {th }}$ century forgers and their strategies, including the copying of authentic paintings kept by these forger groups for themselves, and shares valuable personal and family memories about the inner structure of ateliers and dealership in pre-revolutionary Iran.

\section{AUTHORS}

\section{IVÁN SZÁNTÓ}

Eötvös Loránd University, Budapest \& Austrian Academy of Sciences, Vienne 